\title{
Environmental contamination by parasitic forms in a socially vulnerable community in southern Rio Grande do Sul state: a serious public health problem
}

\section{Contaminação ambiental por formas parasitárias em comunidade em vulnerabilidade social no sul do estado do Rio Grande do Sul: um grave problema de saúde pública}

\author{
Gabriela de Almeida CAPELLA ${ }^{1}$; Natália Berne PINTO${ }^{1}$; Soliane Carra PERERA²; \\ Claudia GIORDANI'; ${ }^{2}$ Micaele Quintana de MOURA ${ }^{1}$; Leonardo Mortagua de CASTRO'²; \\ Tairan Ourique MOTTA²; Débora de Campos AÑAÑA²; Karina Affeldt GUTERRES²; \\ Cristine Cioato da SILVA²; Marlete Brum CLEFF²
}

\footnotetext{
${ }^{1}$ Universidade Federal de Pelotas, Instituto de Biologia, Pelotas - RS, Brazil

${ }^{2}$ Universidade Federal de Pelotas, Faculdade de Veterinária, Pelotas - RS, Brazil
}

\begin{abstract}
In Brazil, a significant percentage of the population lives without basic sanitation, experiencing so-called social vulnerability. The fact that these people share the environment with animals promotes the establishment of zoonotic parasitic infections, as well as the resultant parasitic cycles. Thus, parasites present in the environment must be identified, so that control measures can be recommended. In this context, this study's objective was to evaluate environmental contamination by parasitic forms in a socially vulnerable community in southern Rio Grande do Sul. A total of 100 soil samples collected from the community were processed by a sodium dichromate centrifuge-flotation technique and analyzed by a compound microscope (40X objective) for the identification of parasite eggs, oocysts and cysts. All points were positive for two or more parasites, with the identification of 33.59\% non-identified coccidian oocysts, Strongylida (25.4\%), Ascaridida (21.31\%), Trichuris spp. (8.19\%), Toxocara spp. (3.27\%), Amoebas (4.08\%), Dioctophyma renale (2.45\%), and Giardia spp. (1.63\%). The presence of parasitic forms in all points analyzed surpasses other studies of environmental contamination carried out in the southern region of Brazil. In addition, the identification of several parasitic forms with zoonotic potential is concerning, since it shows the possibility of parasitic transmission to humans and other animals. In view of the results, the conclusion is that the environment analyzed is contaminated by parasitic forms, constituting a serious public health problem. Therefore, implementing educational and preventive measures in the community to control parasites is of crucial importance.
\end{abstract}

Keywords: Contamination. Soil. Parasites. Zoonosis.

\section{Resumo}

No Brasil, uma parcela significativa da população não possui saneamento básico e vive em situação de vulnerabilidade social, compartilhando o ambiente com animais, possibilitando o estabelecimento de infecções parasitárias zoonóticas e a manutenção do ciclo dos parasitos. Assim, para que medidas de controle sejam preconizadas, torna-se necessário a identificação dos parasitos presentes no ambiente. Neste contexto, este trabalho avaliou a contaminação ambiental por formas parasitárias em comunidade de vulnerabilidade social no sul do Rio Grande do Sul. Foram coletadas cem amostras de solo da comunidade, que foram processadas pela técnica de centrifugo-flutuação em solução de dicromato de sódio e analisadas em microscópio composto (objetiva 40X) para a identificação dos ovos, oocistos e cistos de parasitos. Todos os pontos de coleta foram positivos para dois ou mais parasitos, sendo diagnosticados oocistos de coccídios não-identificados (33,59\%), Strongylida (25,4\%), Ascaridida (21,31\%), Trichuris spp. (8,19\%), Toxocara spp. (3,27\%), Amebas (4,08\%), Dioctophyma renale (2,45\%), Giardia spp. (1,63\%). A quantidade de formas parasitárias em todos os pontos analisados supera a contida em outros estudos de contaminação ambiental já realizados na região sul do Brasil. Além disso, a identificação de diversas formas parasitárias com potencial zoonótico é preocupante, pois evidencia a possibilidade de transmissão de parasitoses ao homem e a outros animais. Diante dos resultados, conclui-se que o ambiente em questão está contaminado por formas parasitárias, constituindo um sério problema de saúde pública. Ressalta-se a importância da implantação de medidas educativas e preventivas com a comunidade para o controle dos parasitos.

Palavras-chave: Contaminação. Solo. Parasitos. Zoonoses. 
Correspondence to:

Gabriela de Almeida Capella

Universidade Federal de Pelotas, Instituto de Biologia,

Departamento de Microbiologia e Parasitologia

Campus Universitário S/N, Caixa Postal 354

CEP 96010-900, Pelotas, RS, Brazil

e-mail: capellavet@gmail.com

Received: 9/5/2017

Approved: 11/12/2017

\section{Introduction}

A large part of Brazil's population still lack basic sanitation and lives under social vulnerability (OMS, 2013). Domestic animals can cohabit with humans in environments with poor sanitary conditions (ROSA JUNIOR et al., 2012), causing an increase in parasitic infections (ARAÚJO et al., 2008), with emphasis on companion animals that are important sources of zoonotic parasitosis (BANETH et al., 2016).

According to the Brazilian Institute of Geography and Statistics (IBGE), $44.3 \%$ of the households in the country have at least one dog, estimating a canine population of 52.2 million, and a feline population of 22 million. The southern region of Brazil presents the highest percentage of dogs (IBGE, 2015). The municipality of Pelotas, southern Rio Grande do Sul state (RS), has one domiciled animal for every two inhabitants (DOMINGUES et al., 2015). Despite the numerous benefits generated by living with animals (MACHADO et al., 2008; VIEIRA et al., 2016), the possibility of disease transmission must be addressed, especially diseases of parasitic origin (MOSKVINA; ERMOLENKO, 2016).

Parasitized pets, such as dogs and cats, can contaminate the environment, eliminating up to 20,000 parasitic eggs/ day (OLIVEIRA et al., 2007). The contamination by parasitic forms in sandy soil is important, because sand is able to retain water due to its porous structure, maintaining temperature and humidity favorable for parasite development (ROCHA et al., 2011). In addition, parasite eggs may remain viable for a long time in the environment and, consequently, expose humans and animals to the risk of infection (Oliveira et al., 2007).

Studies indicate that there are millions of people affected by parasites (ARAÚJO et al., 2008; ALMEIDA et al., 2010), with children being more susceptible due to their greater contact with the soil and the practice of geophagy, which increases the potential of infection due to accidental egg ingestion (DESPOMMIER, 2003). Parasitic infection in children may result in nutritional deficiencies, impairing physical and mental development (GURGEL et al., 2005).
In Brazil, studies have demonstrated the contamination of parks and day-care center soils by gastrointestinal nematode eggs in several cities (OLIVEIRA et al., 2007; ARAÚJO et al., 2008). This is also true worldwide (TRAVERSA et al., 2014), especially in less financially favored regions where health care is precarious (VISSER et al., 2011). The studies highlight the presence of Toxocara spp. and Ancylostoma spp., genera already described in soil samples from public areas of Europe, the Americas, Africa, and Asia (TRAVERSA et al., 2014). Parasites of the genera Ancylostoma and Toxocara are responsible for causing, respectively, cutaneous larva migrans, and visceral larva migrans in humans. These zoonosis result in sequels and economic losses with the diagnosis and treatment of parasitized patients (PERUCA et al., 2009).

Due to the importance of parasitic infections, the occurrence of parasites must be identified, both quantitatively and qualitatively. Prophylactic and educational measures must be established considering the concept of "one health", that is, interconnectivity between humans, animals and the environment, and with the collaboration of professionals from different areas (CONRAD et al., 2013).

Investigation of these parasites in feces results in more frequent diagnosis of zoonotic parasitic infections, which can be confirmed by several techniques (COELHO et al., 2013). However, environmental contamination must be more researched. In this context, this study evaluated environmental contamination by parasitic forms in a socially vulnerable community of Pelotas, southern region of RS.

\section{Material and Methods}

The experiment was carried out in a socially vulnerable community in Pelotas, a municipality located in the southern region of Rio Grande do Sul ( $\left.31^{\circ} 46^{\prime} 19^{\prime \prime} S, 52^{\circ} 20^{\prime} 33^{\prime \prime} \mathrm{W}\right)$. The soil samples were processed from July to August 2016. Many animals were diagnosed with parasitic infections in this area, where dogs and cats receive veterinary care through an extension project of the Faculty of Veterinary (FaVet) of the Federal University of Pelotas (UFPel).

Soil samples were collected from four community points for the parasitological evaluation. At each point, $250 \mathrm{~g}$ of soil from four angles and the center were collected. Collections were obtained in the morning with a spatula, and samples were stored in individual plastic bags, previously identified, placed under refrigeration, and sent for parasitological analysis. The twenty samples were divided in the laboratory according to 
the collection point, and each sample was fractionated into five $6 \mathrm{~g}$ parts, totaling 100 samples. The material was processed using the Caldwell \& Caldwell Technique adapted by Gallina et al. (2011), which consists of sample centrifugationflotation in sodium dichromate solution. Subsequently, all samples were analyzed under a compound microscope at $40 \mathrm{X}$ objective to identify parasite forms (eggs, oocysts and cysts).

\section{Results and Discussion}

In sample evaluation $(\mathrm{n}=100), 100 \%$ positivity was observed in all points of the community analyzed, revealing contamination by eggs, oocysts and cysts of more than one parasite at all points collected (Figure 1). Among the positive samples, there were infectious forms of oocysts of non-identified coccidia (33.59\%), Strongylida (25.4\%), Ascarida (21.31\%), Trichuris spp. (8.19\%), Amoebas (4.08\%), Toxocara spp. (3.27\%), Dioctophyma renale (2.45\%), and Giardia spp. (1.63\%), as shown in figure 2.

Multiple contaminations have been reported in other studies (OLIVEIRA et al., 2007; ROCHA et al., 2011). Soil contamination by several species of parasites with zoonotic potential is relevant since it shows the possibility of parasitic infection transmission to humans and animals. Another important fact is that parasite forms resist adverse environments and situations, such as some chemicals, and temperature and humidity variations, remaining viable in the soil for lengthy periods. This resistance not only increases the chances of infection of susceptible hosts but also makes parasitic control difficult (TRAVERSA, 2011).
The most common parasite form was oocysts (33.59\%). However, not all species could be determined, and there is a possibility that some oocysts were non-pathogenic. Other protozoa such as Amoebas, and Giardia spp. werealso observed. The importance of the genus Giardia stands out among these, as it may cause serious morbidity in patients, especially in immunocompromised individuals, being considered a relevant parasite in public health (FREGONESI et al., 2012). In addition, Giardia cysts are resistant to environmental stresses and conventional water treatments, being easily dispersed through water (KARANIS et al., 2007).

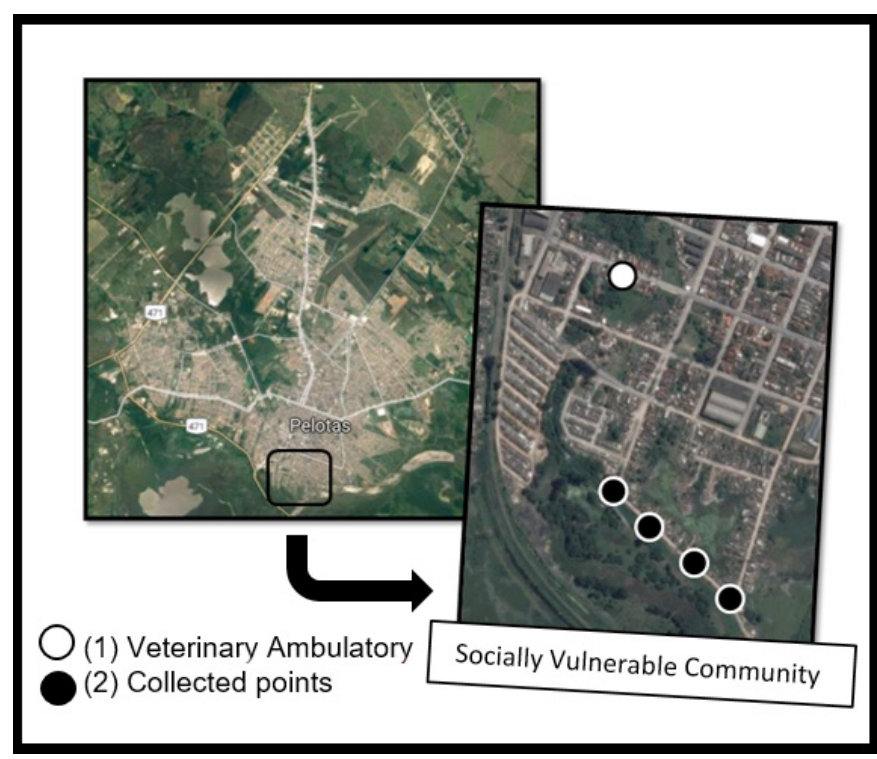

Figure 1-Partial view of the city of Pelotas (1) and the community area under social vulnerability, (2) demonstrating the location of the Veterinary Ambulatory, and the sites where soil samples were collected for parasitological analysis

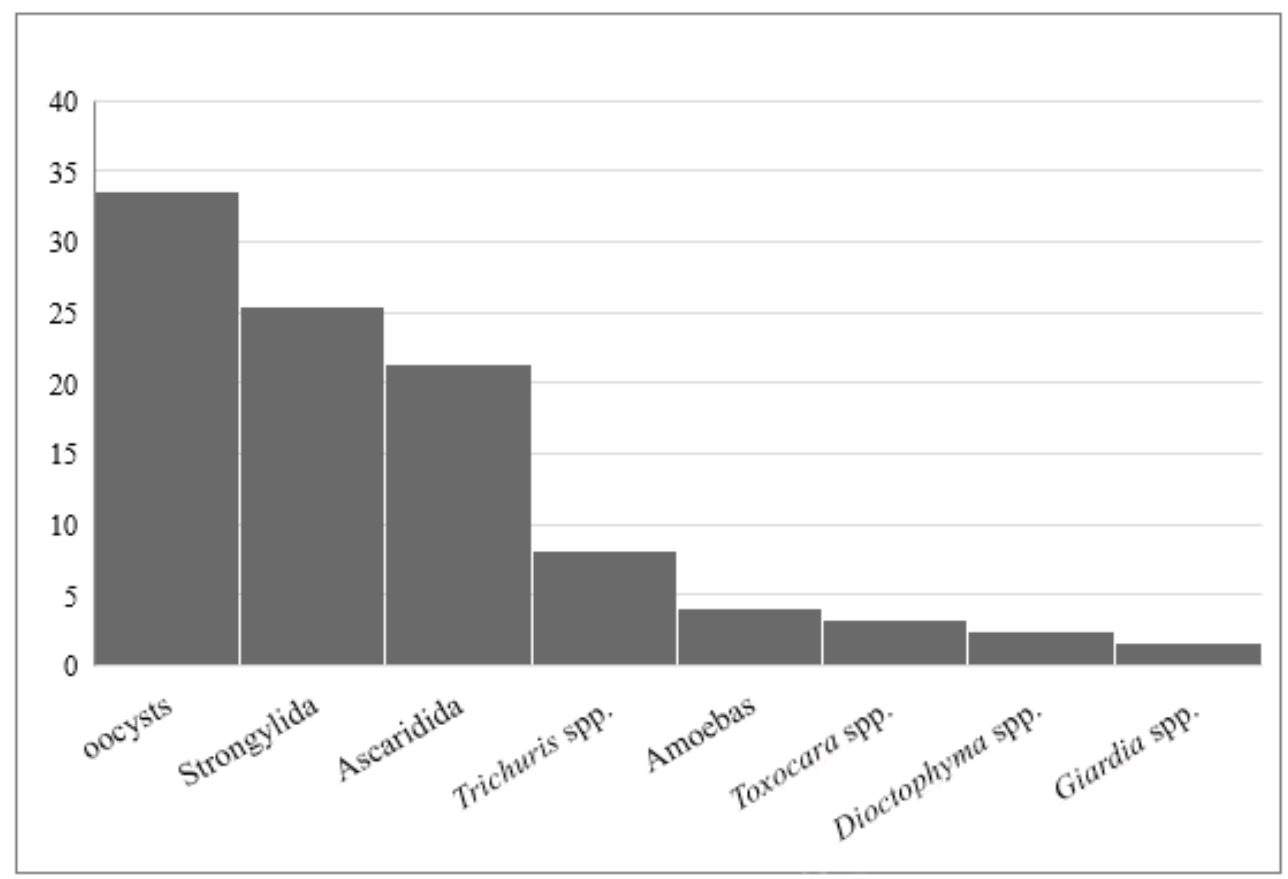

Figure 2 - Percentage of eggs, cysts and oocysts observed in soil samples from a socially vulnerable community in southern Rio Grande do Sul state 
Eggs of parasites belonging to the order Strongylida comprise several genera of animal and human gastrointestinal nematodes. The occurrence of Strongylida in $25.4 \%$ of the samples shows a significant environmental contamination by these parasites since the larvae leave the eggs after 24 to 48 hours in the environment (BOWMAN et al., 2010), which makes it undetectable by the technique. Ancylostoma spp. is frequent in dogs and cats in Brazil (COELHO et al., 2011; MARTINS et al., 2012). These parasites are notable for their zoonotic potential and the possibility of causing Cutaneous Larva Migrans Syndrome (BOWMAN et al., 2010). Humans become infected through the penetration of the larvae into the cutaneous tissue, where they do not complete the cycle, but remain migrating in the skin causing intense pain and pruritus (QUASHIE; TSEGAH, 2015). These parasites are of significant importance for animals since they determine conditions of intense anemia in massive infection, as well as death in puppies due to acute infection and severe anemia (EPE, 2009).

The presence of Ascaridida eggs (21.34\%) can be attributed to the presence of different hosts, since many animal species circulate in the region, such as dogs, cats, swine, horses, and some wild animals. Moreover, because the community studied presents poor sanitary conditions, the possibility that these eggs are of the species Ascaris lumbricoides is not ruled out. This nematode is notable for its high incidence in Brazil. In addition, worldwide estimations are that more than 980 million people are infected by this parasite (SILVA, 2011).

Toxocara spp. is a nematode that stands out because of its high prevalence in canids (NEVES et al., 2014), cats (NIJSSE, 2016) and human populations (MACPHERSON, 2013). The presence of Toxocara spp. eggs in $3.27 \%$ of the samples can be associated with the fact that puppies carry a higher parasite load, being considered important sources of environmental contamination (FAN et al., 2013). However, Toxocara spp. eggs were less frequent compared to other studies carried out in the municipality of Pelotas, where Villela et al. (2009) observed $24.1 \%$ of positive samples on the banks of Laguna dos Patos. Gallina et al. (2011) demonstrated it was the most frequent parasite egg (62\%) in the soil samples of a University Campus, while Moura et al. (2013) found that it was the second most observed parasite in public areas, confirming the presence in $8.8 \%$ of the samples analyzed. Eggs of Toxocara spp. containing infective larvae present in the environment can infect humans, especially children (DESPOMMIER, 2003).
In humans, Toxocara spp. larvae migrate through tissues causing toxocariasis, which can present itself as visceral larvae migrans, ocular larvae migrans, and occult larvae migrans (INAN et al., 2006).

The occurrence of Trichuris spp. eggs in $8.19 \%$ of samples is like that of other soil studies developed in Pelotas, which also observed the presence of this parasite in $14.7 \%$ to $3 \%$ of the samples analyzed (TAVARES et al., 2008; VILLELA et al., 2009; MOURA et al., 2013), making the presence of this helminth in the municipality important. Trichuris vulpis is a ubiquitous parasite with high infection rates in domiciled and non-domiciled animals (TRAVERSA, 2011). Although infrequent, humans may become infected by the ingestion of embryonated eggs present in the soil, food or fomites (DUNN et al., 2002).

The presence of $D$. renale eggs in $2.45 \%$ of samples can be correlated to the presence of animals with dioctophimatosis in the study area, since this parasitosis has been diagnosed in dogs and cats in the same place and is more frequent in animals with street access and less-selective eating habits (KOMMERS et al., 1999). In addition, the community's geographic characteristics, mainly the high-water potential, allows the appearance of paratenic (toads, frogs, and freshwater fish), and intermediate (aquatic oligochaete annelid) hosts of $D$. renale, since the area is located on the banks of the São Gonçalo Channel. Such conditions also allow the development of parasite eggs that require aquatic environment and temperatures between 14 and $30^{\circ} \mathrm{C}$ to form first stage larvae (PEREIRA et al., 2006).

The prevalence of $100 \%$ of positive samples at the points analyzed in this study surpasses other environmental contamination studies carried out in the southern region of Brazil. Tavares et al. (2008) verified a $33.33 \%$ positivity for the soil analyses of 39 parks and housing complexes in the city of Pelotas, with eggs of Toxocara spp., Trichuris spp., Strongyloidea, and protozoan oocysts. Villela et al. (2009) evaluated 920 samples of sandy beach from Laranjal (Pelotas, RS), 87\% of which were positive for Ascaris spp., Toxocara spp., Trichuris spp., and Strongyloidea. Moura et al. (2012) verified the frequency of parasitic contamination of public areas of Pelotas, Rio Grande do Sul, Brazil. Of the 400 samples, 176 (44\%) presented at least one parasitic form, especially eggs of hookworms and Toxocara spp. Prestes et al. (2015) analyzed the contamination of parks in six municipalities of southern Rio Grande do Sul (São Lourenço, Turuçu, Cerrito, Capão do Leão, Pedro Osório, and Jaguarão), selecting 10 parks and collecting 
100 samples in total. After analysis, $41 \%$ of the samples were observed to be positive, with mainly Toxocara spp., followed by Strongyloidea and Ascaris spp.

At the study area, several people survive by collecting waste, which is considered a social vulnerability. Many children in the community directly coexist with dogs, horses, cats, and swine. Rubble is improperly contained, and most of the population has no piped water, garbage collection, and sewage system. Therefore, the study area has favorable conditions for the maintenance of parasitic infections in the environment, and their dissemination to the population. According to Vieira and Amarante (2011), the socioeconomic and cultural level of a population is directly related to the prevalence of parasites. High infection rates in populations are related to factors such as local climate, a high number of inhabitants per residence, inadequate personal hygiene, and food habits, and lack of basic sanitation (VISSER et al., 2011). These factors favor and intensify the transmission and reemergence of parasitic diseases between man, animal and the environment, requiring a broader and unique view of health.

Environmental contamination by parasitic forms was also observed in previous studies in other communities under the situation of social vulnerability, evidencing the potential for community residents' exposure to infection. The presence of eggs of Toxocara spp., hookworms, and nematode larvae was evidenced in a fishing community located in the municipality of Bonito, Mato Grosso do Sul, Brazil, (BRILHANTE et al., 2013). The presence of

\section{References}

ALMEIDA, A. B. P. F.; CÂNDIDO, A. C.; SOUSA, V. R. F. Larvas de helmintos em áreas de recreação de creches de Cuiabá, Mato Grosso. Semina: Ciências Agrárias, v. 31, n. 2, p. 469-472, 2010. doi: 10.5433/1679-0359.2010v31n2p469.

ARAÚJO, N. S.; RODRIGUES, C. T.; CURY, M. C. Helmintos em caixas de areia em creches da cidade de Uberlândia, Minas Gerais. Revista de Saúde Pública, v. 42 , n. 1, p. 150-153, 2008. doi: 10.1590/S003489102008000100021.

BANETH, G.; THAMSBORG, S. M.; OTRANTO, D.; GUILLOT, J.; BLAGA, R.; DEPLAZES, P.; SOLANOGALLEGO, L. Major parasitic zoonoses associated with dogs and cats in Europe. Journal of Comparative eggs of Toxocara spp., Ascaris spp., trichostrongilides, and protozoan oocysts (ONUMA et al., 2014) was observed in a rural community located in Mato Grosso's Pantanal.

The presence of parasitic forms in the soil can also be considered an important biological indicator of fecal and urinary tract contamination, serving as an alert for the transmission of other agents that injure the population (SILVA et al., 1991). The prevalence of parasite eggs observed may also be associated with the time of the year in which the study was conducted, since other authors correlate environmental temperature and rainfall with the number of structures found in sand analyses (ROCHA et al., 2011). Therefore, a study to monitor soil contamination at the study area during the other seasons of the year is of significant importance.

The environmental contamination observed emphasizes the importance of measures of prophylaxis, control, and treatment of the animals in this community, to contain parasitic dissemination. Educating the population is also of vital importance.

\section{Conclusion}

The environment of the community under social vulnerability in central Pelotas, Rio Grande do Sul is contaminated by nematode eggs, and many genera present zoonotic potential, which represents a serious public health problem. Due to the importance of parasitic infections, prophylactic and educational measures must be established to help protect human and animal health.

Pathology, v. 155, n. 1, p. 54-74, 2016. Supplement 1. doi: 10.1016/j.jcpa.2015.10.179.

BOWMAN, D. D.; MONTGOMERY, S. P.; ZAJAC, A. M.; EBERHARD, M. L.; KAZACOS, K. R. Hookworms of dogs and cats as agents of cutaneous larva migrans. Trends in Parasitology, v. 26, n. 4, p. 162-167, 2010. doi: 10.1016/j. pt.2010.01.005.

BRILHANTE, A. F.; NUNES, V. L. B.; DORVAL, M. E. C. Presença de Toxocara spp. e ancilostomídeos em áreas de peridomicílios de uma comunidade pesqueira no Centro-Oeste do Brasil. Brazilian Journal of Veterinary Research and Animal Science, v. 50, n. 1, p. 71-73, 2013. doi: 10.11606/issn.2318-3659.v50ilp71-73. 
COELHO, W. M.D.; AMARANTE, A. F. T. D.; APOLINÁRIO, J. D. C.; COELHO, N. M. D.; BRESCIANI, K. D. S. Occurrence of Ancylostoma in dogs, cats and public places from Andradina city, São Paulo state, Brazil. Revista do Instituto de Medicina Tropical de São Paulo, v. 53, n. 4, p. 181-184, 2011. doi: 10.1590/ S0036-46652011000400001.

COELHO, W. M. D.; GOMES, J. F.; AMARANTE, A. F. T. D.; BRESCIANI, K. D. S.; LUMINA, G.; KOSHINOSHIMIZU, S.; LEME, D. P.; FALCÃO, A. X. A new laboratorial method for the diagnosis of gastrointestinal parasites in dogs. Revista Brasileira de Parasitologia Veterinária, v. 22, n. 1, p. 1-5, 2013. doi: 10.1590/S198429612013000100002.

CONRAD, P. A.; MEEK, L. A.; DUMIT, J. Operationalizing a One Health approach to global health challenges. Comparative Immunology, Microbiology and Infectious Diseases, v. 36, n. 3, p. 211-216, 2013. doi: 10.1016/j. cimid.2013.03.006.

DESPOMMIER, D. Toxocariasis: clinical aspects, epidemiology, ecology, and molecular aspects. Clinical Microbiology Reviews, v. 16, n. 2, p. 265-272, 2003. doi: 10.1128/CMR.16.2.265-272.2003.

DOMINGUES, L. R.; CESAR, J. A.; FASSA, A. G.; DOMINGUES, M. R. Guarda responsável de animais de estimação na área urbana do município de Pelotas, RS, Brasil. Ciência \& Saúde Coletiva, v. 20, n. 1, p. 185-192, 2015. doi: 10.1590/1413-81232014201.19632013.

DUNN, J. J.; COLUMBUS, S. T.; ALDEEN, W. E.; DAVIS, M.; CARROLL, K. C. Trichuris vulpis recovered from a patient with chronic diarrhea and five dogs. Journal of Clinical Microbiology, v. 40, n. 7, p. 2703-2704, 2002. doi: 10.1128/JCM.40.7.2703-2704.2002.

EPE, C. Intestinal nematodes: biology and control. Veterinary Clinics of North America: Small Animal Practice, v. 39, n. 6, p. 1091-1107, 2009. doi: 10.1016/j.cvsm.2009.07.002.

FAN, C. K.; LIAO, C. W.; CHENG, Y. C. Factors affecting disease manifestation of toxocarosis in humans: genetics and environment. Veterinary Parasitology, v. 193, n.4, p. 342-52, 2013. doi: 10.1016/j.vetpar.2012.12.030.
FREGONESI, B. M.; SAMPAIO, C. F.; RAGAZZI, M. F.; TONANI, K. A. A.; SEGURA-MUÑOZ, S. I. Cryptosporidium e Giardia: desafios em águas de abastecimento público. O Mundo da Saúde, v. 36, n. 4, p. 602-609, 2012. doi: 10.15343/0104-7809.2012364602609.

GALLINA, T.; SILVA, M. A. M. P.; CASTRO, L. L. D.; WENDT, E. W.; VILLELA, M. M.; BERNE, M. E. A. Presence of eggs of Toxocara spp. and hookworms in a student environment in Rio Grande do Sul, Brazil. Revista Brasileira de Parasitologia Veterinária, v. 20, n. 2, p. 4142, 2011. doi: 10.1590/S1984-29612011000200016.

GURGEL, R. Q.; CARDOSO, G. S.; SILVA, A. M.; SANTOS, L. N.; OLIVEIRA, R. C. V. Creche: ambiente expositor ou protetor nas infestações parasitárias intestinais em Aracajú, SE. Revista da Sociedade Brasileira de Medicina Tropical, v. 38, n. 3, p. 267-269, 2005. doi: 10.1590/S003786822005000300014 .

INAN, M.; SAKRU, N.; VATANSEVER, U.; BILGI, S. Visceral larva migrans presenting as acute abdomen in a child. Journal of Pediatric Surgery, v. 41, n. 3, p. 7-9, 2006. doi: 10.1016/j.jpedsurg.2005.11.081.

INSTITUTO BRASILEIRO DE GEOGRAFIA E ESTATÍSTICA (IBGE). Pesquisa Nacional de Saúde 2013: acesso e utilização dos serviços de saúde, acidentes e violências: Brasil, grandes regiões e unidades da federação. Rio de Janeiro: IBGE, 2015. 100 p.

KARANIS, P.; KOURENTI, C.; SMITH, H. Waterborne transmission of protozoan parasites: a worldwide review of outbreaks and lessons learned. Journal of Water and Health, v. 5, n. 1, p. 1-38, 2007. doi: 10.2166/wh.2006.002.

KOMMERS, G. D.; ILHA, M. R. S.; BARROS, C. S. L. Dioctofimose em cães: 16 casos. Ciência Rural, v. 29, n. 3 , p. 517-522, 1999. doi: 10.1590/S0103-84781999000300023.

MACHADO, J. A. C.; ROCHA, J. R.; SANTOS, L. M.; PICCININ, A. Terapia assistida por animais (TAA). Revista Científica Eletrônica de Medicina Veterinária, v. 10, p. 1-7, 2008.

MACPHERSON, C. N. L. The epidemiology and public health importance of toxocariasis: a zoonosis of global 
importance. International Journal for Parasitology, v. 43 , n. 12-13, p. 999-1008, 2013. doi: 10.1016/j. ijpara.2013.07.004.

MARTINS, C. M.; BARROS, C. C.; BIER, D.; MARINHO, A. P.; FIGUEIREDO, G. J. M.; HOFFMANN, J. L.; MOLENTO, M. B.; BIONDO, A. W. Dog parasite incidence and risk factors, from sampling after oneyear interval, in Pinhais, Brazil. Revista Brasileira de Parasitologia Veterinaria, v. 21, n. 2, p. 101-106, 2012. doi: 10.1590/S1984-29612012000200006.

MOSKVINA, T. V.; ERMOLENKO, A. V. Helminth infections in domestic dogs from Russia. Veterinary World, v. 9, n. 11, p. 1248-1258, 2016. doi: 10.14202/ vetworld.2016.1248-1258.

MOURA, M. Q.; JESKE, S.; VIEIRA, J. N.; CORRÊA, T. G.; BERNE, M. E. A.; VILLELA, M. M. Frequency of geohelminths in public squares in Pelotas, RS, Brazil. Revista Brasileira de Parasitologia Veterinária, v. 22, n. 1, p. 175-178, 2013. doi: 10.1590/S1984-29612013000100034.

NEVES, D.; LOBO, L.; SIMÕES, P. B.; CARDOSO, L. Frequency of intestinal parasites in pet dogs from na urban area (Greater Oporto, northern Portugal). Veterinary Parasitology, v. 200, n. 3-4, p. 295-298, 2014. doi: 10.1016/j. vetpar.2013.11.005.

NIJSSE, R.; PLOEGER, H. W.; WAGENAAR, J. A.; MUGHINI-GRAS, L. Prevalence and risk factors for patent Toxocara infections in cats and cat owners' attitude towards deworming. Parasitology Research, v. 115, n. 12, p. 4519-4525, 2016. doi: 10.1007/s00436-016-5242-8.

OLIVEIRA, C. B.; SILVA, A. S.; MONTEIRO, S. G. Ocorrência de parasitas em solos de praças infantis nas creches municipais de Santa Maria - RS, Brasil. Revista da FZVA, v. 14, n. 1, p. 174-179, 2007.

ONUMA, S. S.; MELO, A. L. T.; STOCCO, M. B.; SANTARÉM, V. A.; AGUIAR, D. M. Contaminação de solo por ovos de Toxocara spp. e outros geohelmintos em comunidade rural do Pantanal Matogrossense, Brasil. Brazilian Journal of Veterinary Research and Animal Science, v. 51, n. 1, p. 78-81, 2014. doi: 10.11606/ issn.1678-4456.v51ilp78-81.
ORGANIZACIÓN MUNDIAL DE LA SALUD (OMS). Salud en las Américas. Washington: OPS, 2013. Available from: <https://goo.gl/MVWcvC>. Viewed: 3 May 2017.

PEREIRA, B. J.; GIRARDELLI, G. L.; TRIVILIN, L. O.; LIMA, V. R.; NUNES, L. D. C.; MARTINS, I. V. F. Ocorrência de dioctofimose em cães do município de Cachoeiro do Itapemirim, Espírito Santo, Brasil, no período de maio a dezembro de 2014. Revista Brasileira de Parasitologia Veterinária, v. 15, n. 3, p. 123-125, 2006.

PERUCA, L. C. B.; LANGONI, H.; LUCHEIS, S. B. Larva migrans visceral e cutânea como zoonoses: revisão de literatura. Veterinária e Zootecnia, v. 16, n. 4, p. 601-616, 2009.

PRESTES, L. F.; JESKE, S.; SANTOS, C. V.; GALLO, M. C.; VILLELA, M. M. Contaminação do solo por geohelmintos em áreas públicas de recreação em municípios do sul do Rio Grande do Sul (RS), Brasil. Revista de Patologia Tropical, v. 44, n. 2, p. 155-162, 2015. doi: 10.5216/rpt.v44i2.36645.

QUASHIE, N. B.; TSEGAH, E. An unusual recurrence of pruritic creeping eruption after treatment of cutaneous larva migrans in an adult ghanaian male: a case report with a brief review of literature. The Pan African Medical Journal, v. 21, n. 285, p. 1-5, 2015. doi: 10.11604/ pamj.2015.21.285.5612.

ROCHA, S.; PINTO, R. M. F.; FLORIANO, A. P.; TEIXEIRA, L. H.; BASSILI, B.; MARTINEZ, A.; COSTA, S. O. P.; CASEIRO, M. M. Environmental analyses of the parasitic profile found in the sandy soil from the Santos municipality beaches, SP, Brazil. Revista do Instituto de Medicina Tropical São Paulo, v. 53, n. 5, p. 277-281, 2011. doi: 10.1590/S0036-46652011000500007.

ROSA JÚNIOR, A. S.; ARAÚJO, M. D.; AÑAÑA, D. C.; BATISTA, M.; ACOSTA, G. S.; GUTERRES, K. A.; ATHAIDE, C.; STELMAKE, L. L.; CLEFF, M. B. Medicina veterinária na promoção da saúde humana e animal: ações em comunidades carentes como estratégias de enfrentamento da desigualdade social. Revista Ciência em Extensão, v. 8, n. 3, p. 278-283, 2012.

SILVA, J. C.; FURTADO, L. F. V.; FERRO, T. C.; BEZERRA, K. C.; BORGES, E. P.; MELO, A. C. F. L. Parasitismo por 
Ascaris lumbricoides e seus aspectos epidemiológicos em crianças do Estado do Maranhão. Revista da Sociedade Brasileira de Medicina Tropical, v. 44, n. 1, p. 100-102, 2011. doi: 10.1590/S0037-86822011000100022.

SILVA, J. P.; MARZOCHI, M. C. A.; SANTOS, E. C. L. Avaliação da contaminação experimental de areias de praias por enteroparasitas: pesquisa de ovos de Helmintos. Cadernos de Saúde Pública, v. 7, n. 1, p. 90-99, 1991. doi: 10.1590/S0102-311X1991000100008.

TAVARES, A. L. C.; SCAINI, C. J.; MÜLLER, G.; FARIAS, N. A. R.; BERNE, M. E. A. Contaminação do solo de praças de conjuntos habitacionais por helmintos e protozoários em Pelotas, Rio Grande do Sul, Brasil. Vittalle, v. 20, n. 1, p. 59-63, 2008.

TRAVERSA, D. Are we paying too much attention to cardio-pulmonary nematodes and neglecting old-fashioned worms like Trichuris vulpis? Parasites \& Vectors, v. 4, n. 32, p. 1-11, 2011. doi: 10.1186/1756-3305-4-32.

TRAVERSA, D.; REGALBONO, A. F.; DI CESARE, A.; LA TORRE, F.; DRAKE, J.; PIETROBELLI, M. Environmental contamination by canine geohelminths. Parasites \& Vectors, v. 7, n. 67, p. 1-9, 2014. doi: 10.1186/1756-3305-7-67.
VIEIRA, A. C.; AMARANTE, M. K. Prevalência de helmintos no município de Ibiporã, Paraná, no período de 2004 a 2006. Biosaúde, v. 13, n. 1-2, p. 23-37, 2011.

VIEIRA, F. T.; SILVA, R. S.; LEMOS, V. R.; AZEVEDO JÚNIOR, R. R.; NETO, I. V. L.; VIEIRA, M. T.; SANTOS, M. R. D.; JORGE, D. V. B. O. Terapia assistida por animais e sua influência nos níveis de pressão arterial de idosos institucionalizados. Revista de Medicina, v. 95, n. 3, p. 122-127, 2016. doi: 10.11606/issn.1679-9836. v95i3p122-127.

VILLELA, M. M.; PEPE, M. S.; FERRAZ, M. L.; MORAIS, N. C. M.; ARAÚJO, A. B.; RUAS, J. L.; MÜLLER, G.; BERNE, M. E. A. Nota: contaminação ambiental da orla da Laguna dos Patos (Pelotas, RS, Brasil), por parasitos com potencial zoonótico. Vittalle, v. 21, n. 2, p. 69-74, 2009 .

VISSER, S.; GIATTI, L. L.; CARVALHO, R. A. C.; GUERREIRO, J. C. H. Estudo da associação entre fatores socioambientais e prevalência de parasitose intestinal em área periférica da cidade de Manaus (AM, Brasil). Ciência e Saúde Coletiva, v. 16, n. 8, 2011. doi: 10.1590/S141381232011000900016. 